\title{
Enumeration of fungi in barley
}

\author{
C.J. Rabie*, A. Lübben, G.J. Marais, H. Jansen van Vuuren \\ CSIR Food Science and Technology, P.O Box 395, Pretoria 0001, South Africa
}

\begin{abstract}
Estimation of fungal contamination of barley grain is important as certain fungi can proliferate during the malting process. The following factors which may affect the enumeration of fungi were evaluated: dilution versus direct plating, presoaked versus unsoaked grain, five culture media: potato dextrose agar (PDA), acidified Czapek-Dox agar (ACA), pentachloronitrobenzene agar; (PCNB) dichloran rose bengal chloramphenicol agar (DRBC) and malt salt agar; two disinfectants' ethanol/water $(80: 20 \mathrm{v} / \mathrm{v})$ and sodium hypochlorite $\left(3.5 \% \mathrm{w} / \mathrm{v}\right.$ in $\left.\mathrm{H}_{2} 0\right)$. Two barley samples, one having a high incidence of storage fungi and one with a high incidence of field fungi were used and most fungi were identified to species level. Results showed that direct plating was superior to dilution plating for assessing the mycoflora of barley. Unsoaked grain gave significantly higher counts than presoaked grain in the case of Alternaria alternata, Rhizopus oryzae, Epicoccum nigrum and Mucor spp. Presoaked grain resulted in higher counts of Penicillium spp. Chlorine disinfection resulted in significantly higher counts of Aspergillus flavus, Eurotium spp. and Penicillium spp. Ethanol disinfection resulted in higher counts of Mucor spp., Phoma sorghina, Rhizopus oryzae and Aspergillus restrictus. PDA and ACA, in general gave some what better results than DRBC for both field and storage fungi. PCNB consistently gave the highest Fusarium counts. More than thirty fungal genera were found in the two samples. C) 1997 Elsevier Science B.V.
\end{abstract}

Keywords: Barley; Enumeration; Fungi; Methodology

\section{Introduction}

Estimation of fungal contamination of barley grain is important as fungi can proliferate during storage and the 4-5 day malting process (Clarke and Hill, 1981; Hill and Lacey, 1983; Cooke and La Berge, 1988; Petters et al., 1988). The presence of fungi in malt may pose a health hazard due to

\footnotetext{
* Corresponding author. Fax: + 27128414790
}

the production of mycotoxins (Nummi et al., 1975), and affect the resultant beer by causing off-flavours and colours and, in some instances, gushing (Haikara, 1983; Vaag, 1985). Under certain circumstances some fungal species and/or their products may also affect germination, $\alpha$ amylase production and even the subsequent fermentation process by having an adverse effect on the yeast. Microbial activity may also play a role in the so-called innate post-harvest dormancy in barley (Kelly and Briggs, 1992). 
As high levels of infection in barley are detrimental to good quality malt and beer, it is important to quantify fungal contamination. Various

Table 1

Fungi isolated from barley kemels

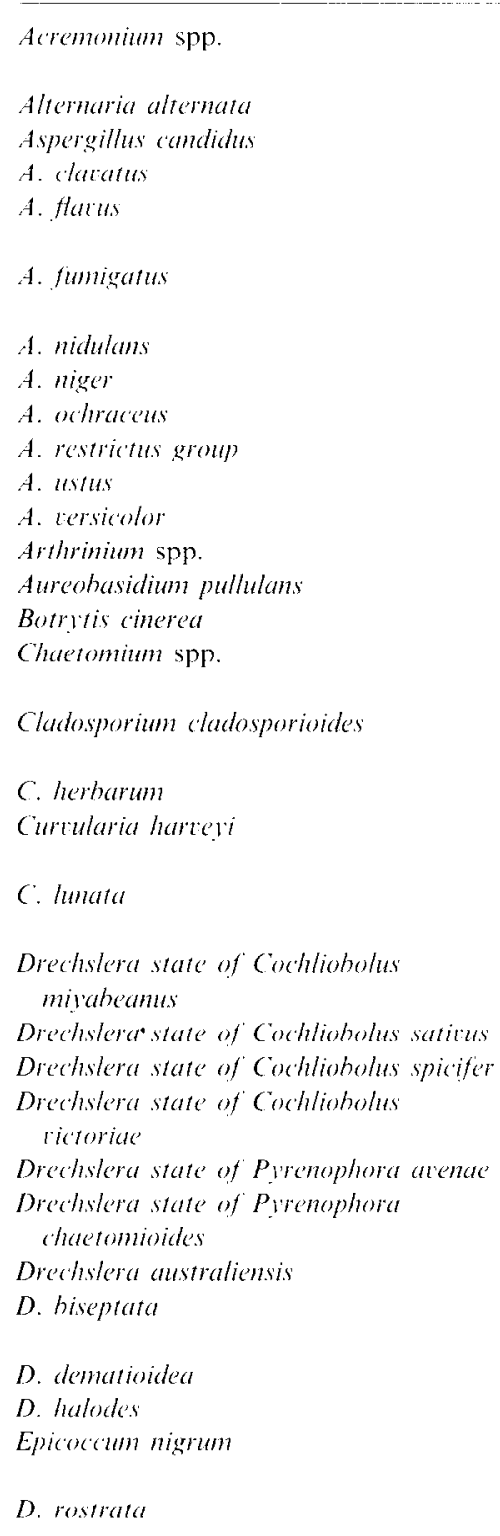

Eurotium

amstelodami

E. chetalieri

E. repens

E. rubrum

Fusariam acuminatum

F. chlamidospo-

rim

F. equiseti

F. graminearum

F. momiliforme

F. oxysportm

F. prace

F. sambucinum

F. sciopi

F. solani

F. subglutinans

Geotrichum

candidum

Gonatobotrys

spp.

Mucor spp.

Neocosmospora

spp.

Nigrospora

oryzate

Pacilomyes

spp.

Papulaspera spp.

Penicillitim spp.

Phoma spp.

P. sorghina

Pithomves spp.

Rhizopus orleat

Scopulariopsis

spp.

Sordaria spp.

Stemphylium spp.

Syncephalastram

racemostum

Thielatia spp.

Trichothecium

roseum

Trichoderma spp.

Glocladium spp.
Table 2

Average incidence of dominant fungal species in two direct plated barley samples

\begin{tabular}{|c|c|c|}
\hline \multirow[t]{2}{*}{ Dominant species } & \multicolumn{2}{|c|}{ Kernels infected" (") } \\
\hline & $\begin{array}{l}\text { Field fungus } \\
\text { sample }\end{array}$ & $\begin{array}{l}\text { Storage fungus } \\
\text { sample }\end{array}$ \\
\hline Alternaria alternata & 96 & 4 \\
\hline Aspergillus candudus & tr & 94 \\
\hline A. Hanus & & 13 \\
\hline A. restrictus & & 41 \\
\hline Chaetominm spp. & 2 & 46 \\
\hline Cladosporiam spp. & 5 & \\
\hline Curtularia spp. & 8 & \\
\hline Epicoceum nigrum & 8 & \\
\hline $\begin{array}{l}\text { Eurofium amstelo- } \\
\text { dami }\end{array}$ & & 77 \\
\hline E. cheratiefi & & 94 \\
\hline E. ropens & & 7 \\
\hline $\begin{array}{l}\text { Forseriam chlamy - } \\
\text { dosponmm }\end{array}$ & 7 & \\
\hline F. equiseti & 28 & \\
\hline F. moniliforme & 2 & \\
\hline F. oxyporm & 7 & \\
\hline F. sambucimum & 2 & $\ldots$ \\
\hline F. sirpi & 2 & \\
\hline F. subghtutinans & 6 & \\
\hline Mucor spp. & $-\ldots-$ & 19 \\
\hline Paecilomices spp. & $\ldots$ & 9 \\
\hline Penicillitm spp. & & 74 \\
\hline Phoma sorghina & 96 & \\
\hline Rhi=opus spp. & 23 & 4 \\
\hline
\end{tabular}

"Average of four replications on the mediun with the highest count for both soaked and unsoaked seed for both disinfectants.

"Not found.

laboratory methods have been used for the enumeration or quantification of fungi in grains. These include different plating methods (Hill and Lacey, 1983; Sauer and Burroughs, 1986; Kirby, 1987; Flannigan, 1991; Trojanowska, 1991); fluorescent antibody techniques (Warnock, 1971); direct microscopical methods (Warnock. 1971); ELISA techniques (Clark, 1981; Kistner and Johannsen, 1991); ergosterol (Seitz et al., 1979) and chitin determinations (Roberts et al., 1987); Howard mould counts (Jarvis et al., 1983) and colour measurements (Rabie and Lübben, 1993).

A variety of factors, including the use of surfactants, soaking, method of comminution of surface 
disinfection, culture media, pre-treatment of grain, sample size and incubation conditions can influence results obtained by plating methods (Mulinge and Chesters, 1970; Jarvis et al., 1983; Speakman and Kruger, 1983; Pitt and Hocking, 1985; King et a1., 1986; Samson et al., 1992).

In this study the following parameters which may affect the enumeration of both field and storage fungi in barley grain were evaluated: (1) dilution versus direct plating; (2) presoaked versus unsoaked grain; (3) five culture media; and (4) two surface disinfectants.

\section{Materials and methods}

\subsection{Barley}

Two barley samples (Clipper cultivar), one having a high incidence of field fungi, the other a high incidence of storage fungi, were evaluated. One sample was obtained from a silo which had previ-

Table 3

Average dilution plate counts of the dominant fungal species in two barley samples

\begin{tabular}{lll}
\hline Dominant species & \multicolumn{2}{l}{ Average count } \\
\cline { 2 - 3 } & $\begin{array}{l}\text { Field fungus } \\
\text { sample }\end{array}$ & $\begin{array}{l}\text { Storage fungus } \\
\text { sample }\end{array}$ \\
\hline $\begin{array}{ll}\text { Alternaria alternata } \\
\text { Aspergillus candidus }\end{array}$ & $\begin{array}{l}3.4 \times 10^{2} \\
\mathrm{~b}\end{array}$ & \\
A. flavus & - & $4.3 \times 10^{6}$ \\
A. niger & - & $5.2 \times 10^{2}$ \\
Aureohasidium pul- & $9.3 \times 10^{1}$ & $2.5 \times 10^{2}$ \\
$\quad$ lulans & & \\
Cladosporium spp. & $2.1 \times 10^{2}$ & - \\
Eurotium spp. & - & $6.4 \times 10^{3}$ \\
Fusarium spp. & $4.2 \times 10^{2}$ & $1.5 \times 10^{6}$ \\
Mucor spp. & $4 \times 10^{2}$ & $2.9 \times 10^{3}$ \\
Paecilomyces spp. & - & $2.5 \times 10^{1}$ \\
Penicillim spp. & - & - \\
Phoma sorghina & $2.8 \times 10^{3}$ & \\
\hline
\end{tabular}

\footnotetext{
"Average of four replications on the medium with the highest count on both soaked and unsoaked seed for both disinfectants.

${ }^{\mathrm{b}}$ Not found.
}

ously shown a high incidence of storage fungi, the other was a sample taken directly from the field. Both samples were dried to a $12 \%$ moisture content and kept in linen bags at $4^{\circ} \mathrm{C}$ until used.

\subsection{Culture media}

Five culture media were evaluated.

\subsubsection{Potato dextrose agar (PDA)}

PDA (Difco, USA) was prepared according to manufacturer's instructions.

\subsubsection{Malt salt agar (MSA)}

MSA was prepared using: $20 \mathrm{~g}$ malt extract (Difco), $75 \mathrm{~g} \mathrm{NaCl}, 15 \mathrm{~g}$ agar (Difco), $1000 \mathrm{ml}$ distilled $\mathrm{H}_{2} \mathrm{O}$. $\mathrm{NaCl}$ was dissolved in $300 \mathrm{ml}$ distilled $\mathrm{H}_{2} \mathrm{O}$ (A), the malt extract and agar in 700 $\mathrm{ml}$ distilled $\mathrm{H}_{2} \mathrm{O}$ (B). After autoclaving separately for $15 \mathrm{~min}$ at $121^{\circ} \mathrm{C}, \mathrm{A}$ and $\mathrm{B}$ were added together.

\subsubsection{Acidified Czapek-Dox agar ( $A C A$ )}

Czapek solution agar (Difco) was prepared according to manufacturer's instructions. After autoclaving for $15 \mathrm{~min}$ at $121^{\circ} \mathrm{C}, 9 \mathrm{ml}$ lactic acid solution $(55 \mathrm{ml}$ of $90 \%$ lactic acid per $145 \mathrm{ml}$ sterile distilled water) and $1 \mathrm{ml}$ Tergitol (Sigma) were added per $1000 \mathrm{ml}$ distilled water. Final $\mathrm{pH}$ was 3.4 .

\subsubsection{Pentachloronitrobenzene agar}

PCNB was prepared from: $15 \mathrm{~g}$ peptone (Difco), 1 g $\mathrm{KH}_{2} \mathrm{PO}_{4}, 0.5 \mathrm{~g} \mathrm{MgSO}_{4} 7 \mathrm{H}_{2} \mathrm{O}, 2 \mathrm{~g}$ pentachloronitrobenzene, $15 \mathrm{~g}$ agar, (Difco), 1000 $\mathrm{ml}$ distilled $\mathrm{H}_{2} \mathrm{O}, 0.125 \mathrm{~g}$ Novobiocin (Sigma). It was then autoclaved for $15 \mathrm{~min}$ at $121^{\circ} \mathrm{C}$.

\subsubsection{Dichloran rose bengal chloramphenicol agar}

DRBC was prepared as recommended by Pitt and Hocking (1985): glucose, $10 \mathrm{~g}$; peptone (Difco), $5 \mathrm{~g} ; \mathrm{KH}_{2} \mathrm{PO}_{4}, 1 \mathrm{~g} ; \mathrm{MgSO}_{4} 7 \mathrm{H}_{2} \mathrm{O}, 0.5 \mathrm{~g}$; agar (Difco), $15 \mathrm{~g}$; distilled $\mathrm{H}_{2} \mathrm{O}, 1000 \mathrm{ml}$; rose bengal $\left(5 \%(\mathrm{w} / \mathrm{v})\right.$ in distilled $\left.\mathrm{H}_{2} \mathrm{O}\right), 0.5 \mathrm{ml}$; chloramphenicol, $100 \mathrm{mg}$; dichloran $(0.2 \%(\mathrm{w} / \mathrm{v})$ in ethanol), $1 \mathrm{ml}$. It was then autoclaved at $121^{\circ} \mathrm{C}$ for 15 min and kept in the dark until use. 
Table 4

Average percentage fungal infection of soaked and unsoaked field fungus sample after treatment with ethanol and chlorine

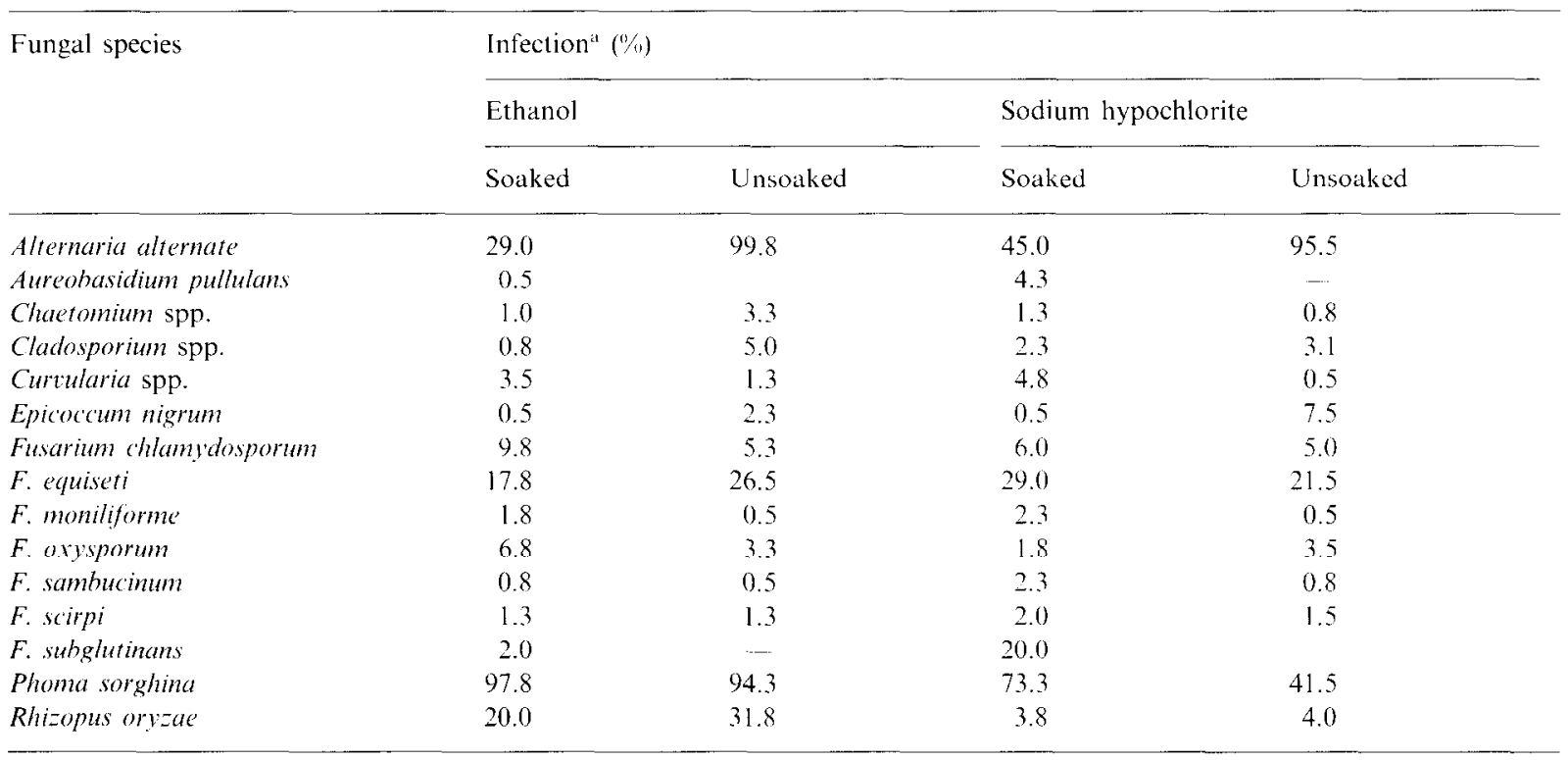

"Average of four replicates on the medium showing the highest count.

\subsubsection{Surface disinfection}

Two disinfectants were used: $80 \%(\mathrm{v} / \mathrm{v})$ ethanol in water for $1 \mathrm{~min}$ and sodium hypochlorite $3.5 \%$ $(\mathrm{w} / \mathrm{v})$ for $1 \mathrm{~min}$. A $50 \mathrm{~g}$ grain sample was weighed out and shaken for $1 \mathrm{~min}$ in $100 \mathrm{ml}$ of disinfectant. After decanting, the grain samples were washed three times in sterile distilled water before plating out.

\subsection{Plating procedures}

\subsubsection{Direct plating}

After surface disinfection, the washed kernels were placed (5/9.5 cm Petri dish) on the surface of the solidified agars using sterile forceps. One hundred kernals were used in each treatment and replicated four times.

\subsubsection{Dilution plating}

After disinfection, $50 \mathrm{~g}$ of grain was milled to a fine meal in a sterile mill. A 10:1 series was prepared by suspending $1 \mathrm{~g}$ of meal in $10 \mathrm{ml}$ sterile distilled water and diluting eight times using $1 \mathrm{ml}$ of suspension. Each dilution $(1 \mathrm{ml})$ was added to $15 \mathrm{ml}$ medium pre-cooled to $48^{\circ} \mathrm{C}$ and poured into $9.5 \mathrm{~cm}$ plastic Petri dishes. Plates were incubated upright at $25^{\circ} \mathrm{C}$ for 4 days in the dark, after which they were placed under a combination of black light/incandescent light with a 12 h light $/ 12$ h dark cycle for 4 days at $20^{\circ} \mathrm{C}$. Each treatment was replicated four times. Fungi which grew were identified to species level where possible.

\subsubsection{Presoaking}

Surface disinfected seeds $(50 \mathrm{~g})$ were soaked in sterile distilled water $(200 \mathrm{ml})$ for $36 \mathrm{~h}$ at $18^{\circ} \mathrm{C}$ before plating out.

\subsubsection{Experimental design}

Two barley samples, one contaminated by storage fungi and the other by field fungi, were used, both for direct and dilution. Sterilization of each treatment was carried out with both ethanol and sodium hypochlorite, on both unsoaked and soaked grain. All treatments were plated on all five media using four replications. 
Table 5

Average percentage fungal infection of soaked and unsoaked storage fungus sample after treatment with ethanol and chlorine

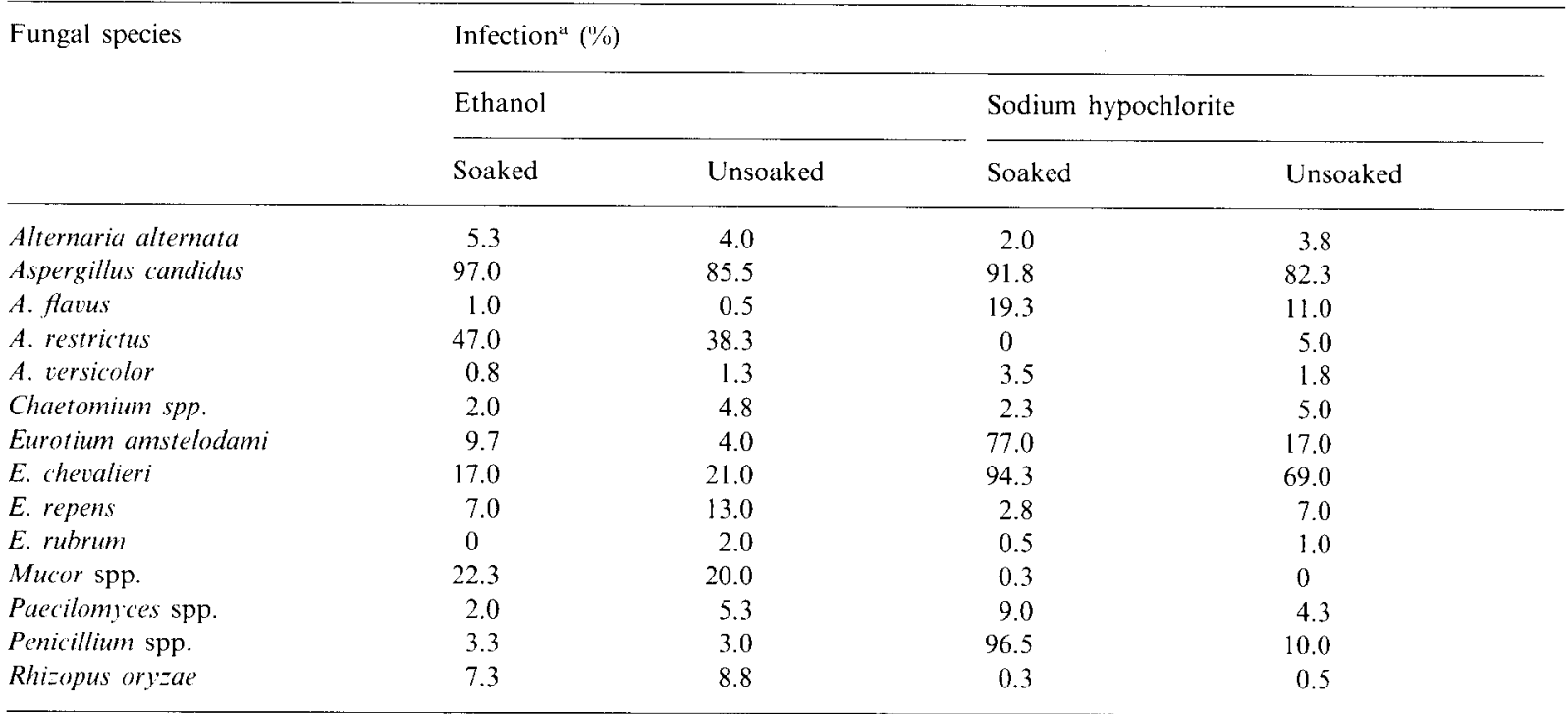

"Average of four replicates on medium showing the highest count.

\section{Results}

More than 30 fungal genera were isolated and identified from the two barley samples (Table 1). Of these, between six and 15 species occurred regularly and were found in all replicates, whereas the majority of the remaining species occurred in such low numbers that they could not be included in the statistical analysis.

\subsection{Dilution versus direct plating}

The species that occurred most frequently in the two samples using dilution and direct plating are shown in Tables 2 and 3. A much larger variety of species of both field and storage fungi were enumerated using the direct plating method. Eurotium species were especially difficult to distinguish using dilution plating. This was also the case with Aspergillus restrictus where direct plating showed a $41 \%$ incidence in individual kemels whercas this species was not found using dilution plating (Tables 2 and 3). Dilution plating also did not reflect relative high percentages of infection with Chaetomium and Mucor species.
The relative incidence of Paecilomyces spp. was apparently higher using dilution plating, though results of the two techniques cannot be compared directly. Dilution plating was also apparently more effective for enumeration of Fusarium species under conditions of high infection with storage fungi. In the sample high in field fungi both methods identified the same three species as dominant, but a greater diversity of species was found using direct plating.

\subsection{Soaked vs. unsoaked grain and ethanol vs. chlorine}

The results in Tables 4 and 5 give a summary of the effect of soaking as an average for both disinfectants on all media used. The statistical analysis as well as interactions between soaking, disinfectants and media, are shown in Tables 6 and 7. Results of the field fungus sample (Table 6) show that, except for the incidence of Alternaria alternata, Epicoccum nigrum and Fusarium moniliforme, soaking did not have a significant effect. $A$. alternata and $E$. nigrum occurred in significantly higher numbers on unsoaked grain, whereas numbers of $F$. moniliforme were lower. 


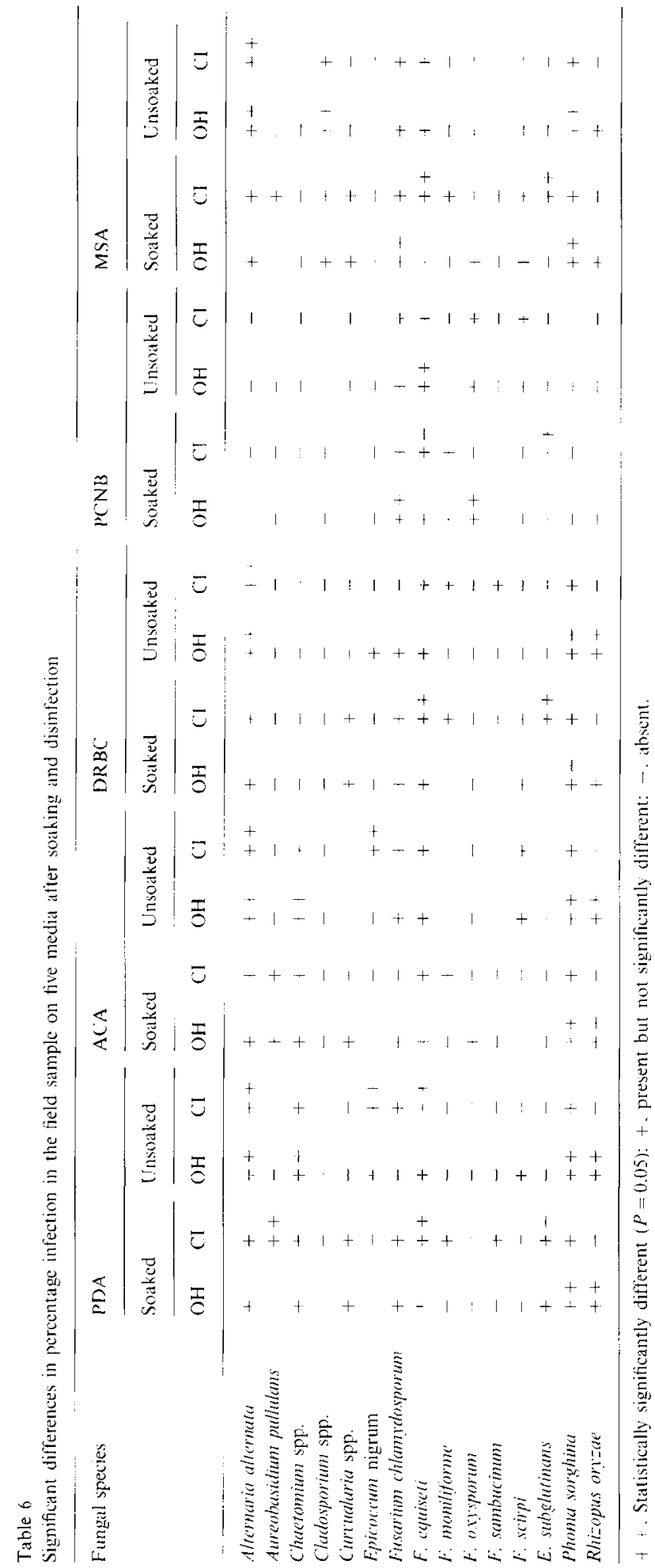




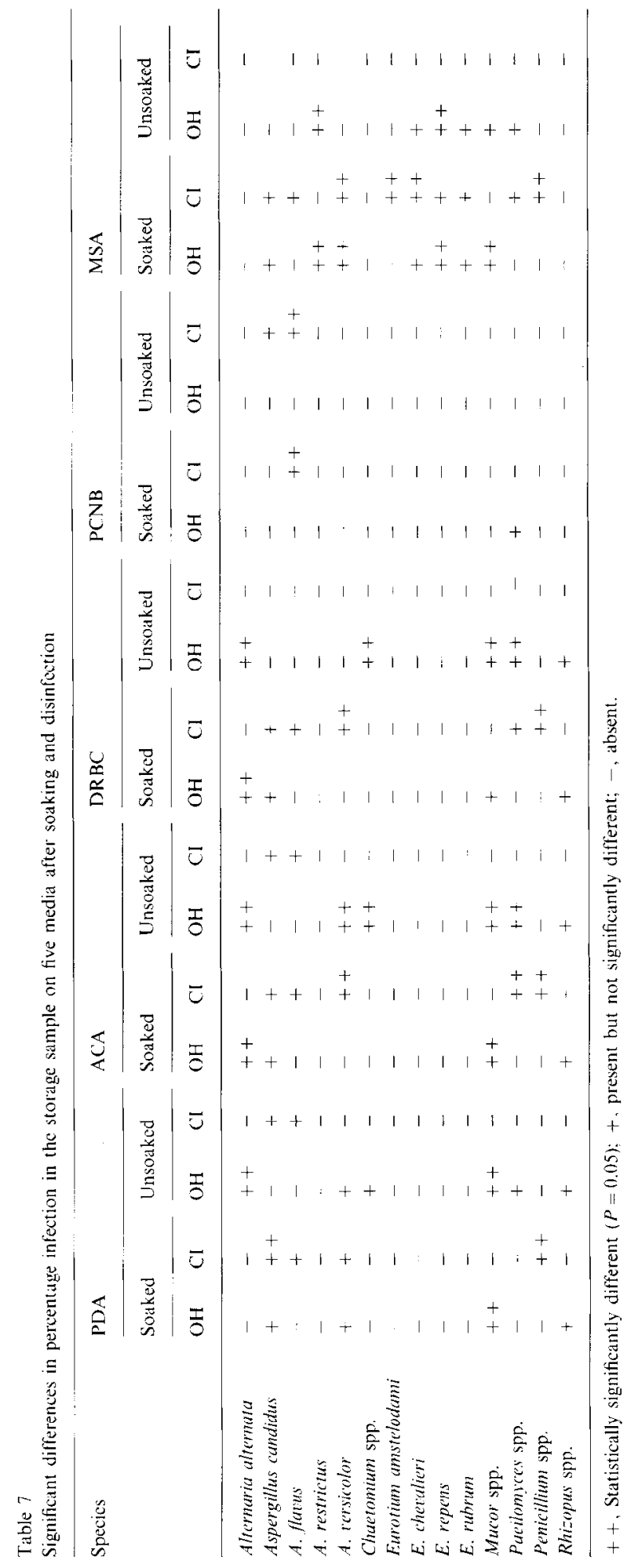


Table 8

Significant differences in percentage infection of all treatments of the field fungus sample on five media

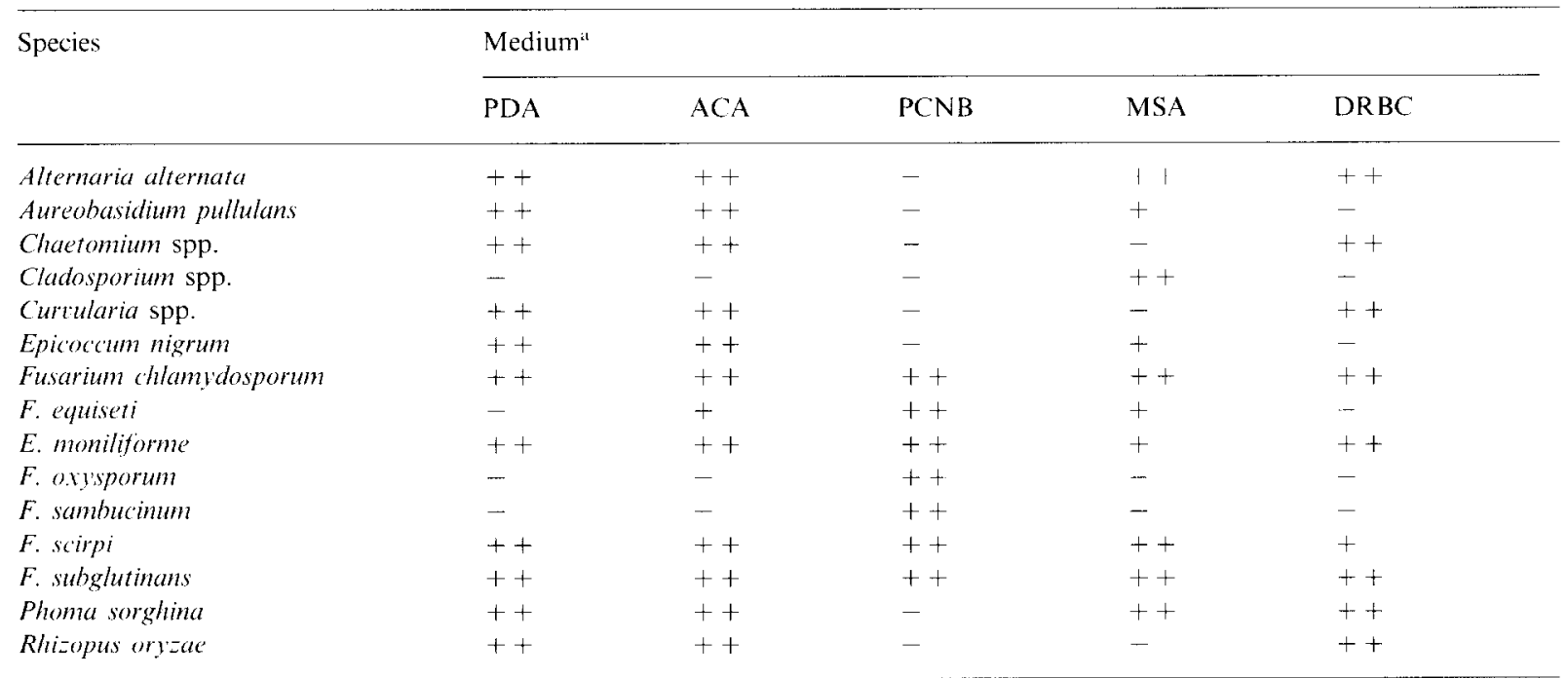

++ , Statistically significant different $(P=0.05) ;+$, present but not significantly different; - , absent.

"Combination of all soaking and sterilization treatments.

Disinfection with ethanol resulted in significantly higher counts of Phoma sorghina and Rhizopus oryzae, but the use of chlorine gave significantly higher counts of Fusarium subglutinans (Table 6).

In the case of the storage fungus sample (Tables 5 and 7) statistically significant higher counts of Penicillium spp. and Eurotium amstelodami were found after soaking. Soaking did not have a significant effect on the numbers of the other species. In this sample, Alternaria alternata, Aspergillus restrictus, Mucor spp. and Rhizopus oryzae all occurred in significantly higher numbers when ethanol was used as a disinfectants (Tables 5 and 7). Aspergillus flavus, Eurotium amstelodami, E. chevalieri and Penicillium spp., on the other hand, were best enumerated with chlorine as a sterilant (Table 7). In some cases significant interactions were observed between the soaking treatments and disinfectant. Penicillium spp. and E. amstelodami, for instance, occurred in significantly higher numbers after chlorine treatment only if the grain was presoaked. In contrast, other species such as E. chevalieri and Aspergillus flavus, where chlorine

Table 9

Significant differences of all treatments in the ground field sample on five media

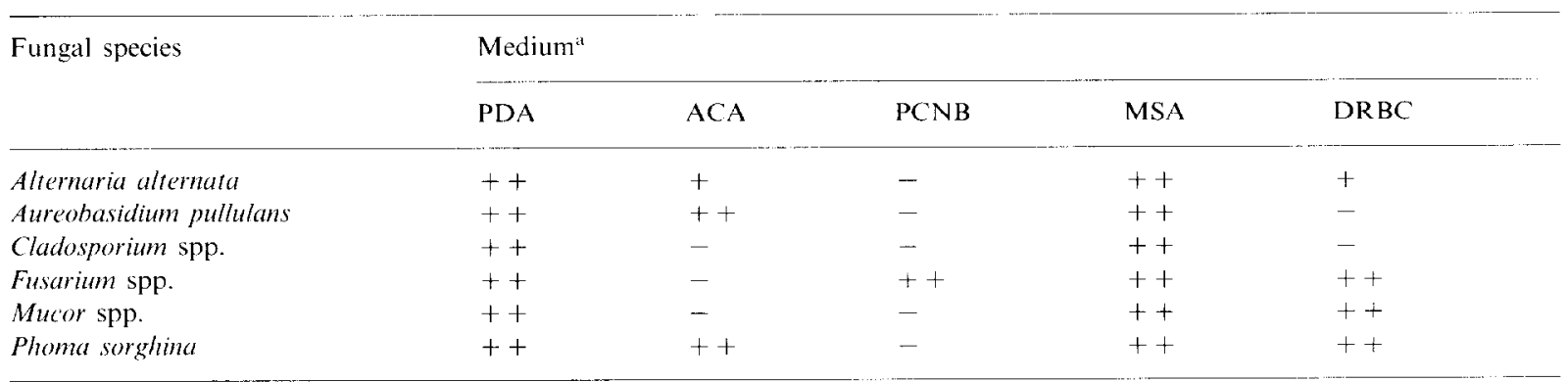

++ . Statistically significant $(P=0.05) ;+$, present but not significantly different; - , absent.

"Combination of all soaking and sterilization treatments. 
Table 10

Significant differences in percentage infection of all treatments of the storage fungus sample on five media

\begin{tabular}{|c|c|c|c|c|c|}
\hline \multirow[t]{2}{*}{ Species } & \multicolumn{5}{|c|}{ Medium } \\
\hline & PDA & $\mathrm{ACA}$ & PCNB & MSA & DRBC \\
\hline Alternaria altenata & ++ & ++ & - & - & ++ \\
\hline Aspergillus candidus & $+t$ & ++ & - & ++ & ++ \\
\hline A. flavus & ++ & ++ & $+t$ & - & $+t$ \\
\hline Chactonium spp. & ++ & - & - & - & ++ \\
\hline Eurotium amstelodami & & - & - & - & ++- \\
\hline E. chevalieri & - & - & - & ++ & - \\
\hline E. repens & - & - & - & ++ & - \\
\hline E. rubrum & - & - & - & ++ & - \\
\hline Mucor spp. & ++ & ++ & - & ++ & + \\
\hline
\end{tabular}

++ , Statistically significant different $(P=0.05) ;+$, present but not significantly different; - , absent.

"Combination of all soaking and sterilant treatments.

gave better results than ethanol, presoaking had no effect.

\subsection{Culture media}

The efficacy of different culture media on the enumeration of fungi in these two samples are given in Tables $8-11$. Only those results that were statistically significant are given. Results for the field fungus sample when direct plated (Table 8), showed that PCNB medium was superior to the other media studied for the enumeration of Fusarium spp. On the whole, results obtained with PDA, ACA and DRBC were not significantly different except that DRBC was inferior in the enumeration of Auriobasidium pullulans, Epicoccum nigrum and Fusarium scirpi. Dilution counts on the field fungus sample (Table 9) suggested that MSA, followed by PDA, gave the best results but, in total only a few species were enumerated.

Table 11

Significant differences in viable counts in all treatments of the ground field sample on five media

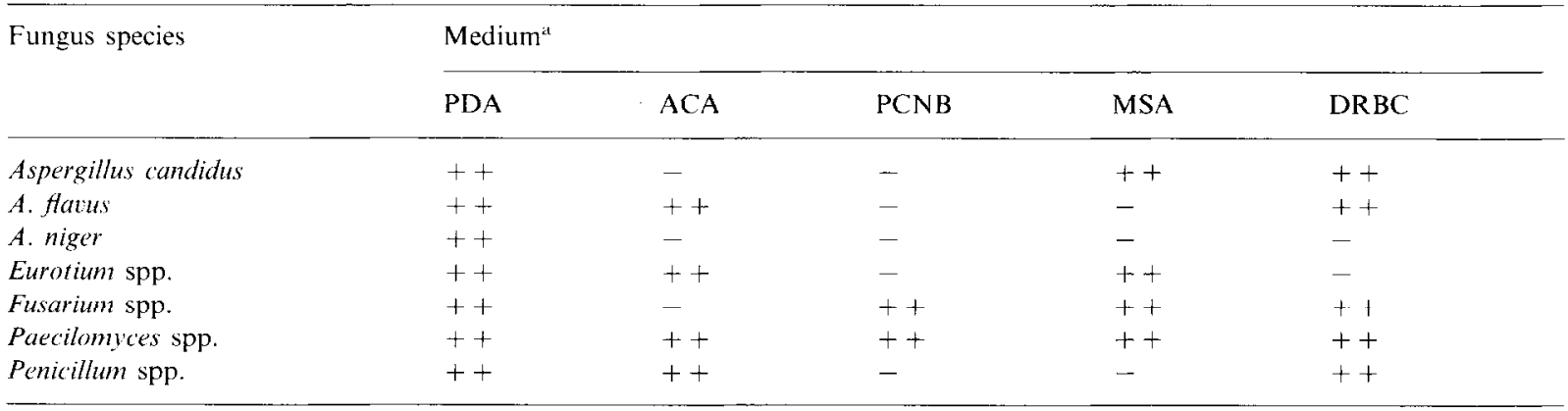

++ , Statistically significant different $(P=0.05) ;+$, present but not significantly different; - , absent.

"Combination of all soaking and sterilization treatments. 
Results for the storage fungus, using direct plating (Table 10), showed no significant differences between PDA, ACA, MSA and DRBC across the whole spectrum of species. As expected, MSA was superior for the enumeration of Eurotium spp. and Aspergillus restrictus. Far fewer species were found using dilution plating, under these conditions PDA gave better results.

\section{Discussion}

The aim of this study was to evaluate different microbiological procedures in order to reduce the enumeration procedures to its simplest form viz. the least number of media, sterilants, etc. The results indicate that the choice of method will, to some extent, depend on which fungus species are considered to be most important and, in particular, whether grain is freshly harvested or has been stored. No single set of parameters will equally enumerate all species that occur in a specific sample. For the two samples examined here the simplest method would be to use direct plating on PDA, MSA and PCNB, unsoaked grain and ethanol as disinfectant.

It was perhaps not appropriate to include DRBC medium in this study, seeing that it is known that toxic compounds may form under light treatments as used for sporulation in this study. The results given here give no information about the utility of DRBC incubated in darkness.

\section{Acknowledgements}

The authors gratefully acknowledge the South African Wheat Board and S A Maltsters (Pty) Ltd for financial support of this study.

\section{References}

Clark, M.F. (1981) Immunosorbent assays in plant pathology. Ann. Rev. Phytopathol. 19,83 106.

Clarke, J.H and Hill S.T. (1981) Mycofloras of moist stored barley during sealed storage in farm and laboratory silos. Trans. Br. Mycol. Soc. 77, 557.565

Cooke, L.A and La Berge, D.E. (1988) Barley nobody mals.
MBAA Tech. Q. 25. 36-40.

Flannigan, B. (1991) Detection and quantification of toxigenic moulds. In: J.E. Smith, and R.S. Henderson, (editors), Mycotoxins and Animal Foods. CRC Press. London, pp. $57-80$.

Haikara, A. (1983) Malt and beer from barley artificially contaminated with Fusarium in the field. European Brewery Convention. Proc. 19th Congr., pp. 401-408.

Hill, R.A. and Lacey, J. (1983) Factors determined the microflora of stored barley grain. Ann. Appl. Biol. 102, $4617 \cdot 483$

Jarvis, B.. Seiler, D.A.L.. Ould. A.J.L. and Williams, A.P. (1983) Observations on the enumeration of moulds in food and feeding stuffs. J. Appl. Bacteriol. 55, 325 336.

Kelly. L. and Briggs, D.E. (1992) The influence of the grain microflora on the germinative physiology of barley. J. Inst. Brew. 98, 329-334.

King, A.D., Pitt, J.I., Beuchat, L.R. and Corry, J.E.L.. (1986) In: A.D. King, J.I. Pitt, L.R. Beuchat and J.E.L. Corry (editors), Methods for the Mycological Examinaion of Food. Plenum Press, New York.

Kirby, J.J.H. (1987) A comparison of serial washing and surface sterilization. Trans. Br. Mycol. Soc. 88. 559 - 562.

Kistner. B.M. and Johannsen, E. (1991). Food safety and quality assurance. In: M.R.A. Morgan, C.J. Snith, and D.A. Williams, (editors). Applications of Immunoassay Systems. Elsevier, Amsterdam, pp. 343350.

Mulinge. S.K and Chesters, C.G.C. (1970) Methods of isolating the microflora of moulding. high moisture barley in partially scaled silos. Ann. Appl. Biol. 65, 285 - 292.

Nummi. M.. Niku-Paavola, M.L. and Enari, T.M. (1975) Der Finflu/s eines Fusarium toxins auf dic Gersten-Vermälzung. Brauwissenschaft 28, 130-133.

Petters. H. I., Flannigan, B. and Austin, B. (1988) Quantitative and qualitatives studies of the microflora of barley malt production. I. Appl. Bactcriol. 65, 279297.

Pit1, J.I. and Hocking. A.D. (1985) Fungi and Food Soilage. Academic Press, Sydney.

Rabie, C.J. and Lubben, A. (1993) The mycoflora of South African barley and barley malt. The Institute of Brewing. Proc. 4th Scientific and Technical Convention. pp. $55 \% 73$.

Roberts, C.A. Moore, K.J. Grallis, D.W.. Walgenbach, R.P. and Kirby, H.W. (1987) Quantification of mould in hay by near infrared reflectance spectroscopy. J. Dairy Sci. 70. 25602564.

Samson. R.A.. Hocking, A.D., Pitt. J.I, and King, A.D. (1992) In: R.A. Samson, A.D. Hocking, J.I. Pitl and A.D. King (cditors). Modern Methods in Food Mycology. Elsevier, Amsterdam.

Saluer, D.B. and Burroughs, R. (1986) Disinfection of seed surfaces with sodium hypochlorite. Phytopathology 76 , 745749.

Seitz. I..M.. Saluer, D.B., Burroughs, R.. Mohr. H.E. and Hubbard. J.D. (1979) Ergosterol as a measure of fungal growth. Phytopathology 69, 12021203.

Spcakman, J.B. and Kruger, W. (1983) A comparison of methods to surface sterilize wheat seeds. Trans. Br. Mycol. Soc. 80, 374-376. 
Trojanowska, K. (1991) Evaluation of cereal grain quality using mycological methods. In: J. Chelkowski (editor), Cereal grain: Mycotoxins, fungi and quality in drying and storage. Elsevier, Amsterdam, pp. 185-215.

Vaag. P. (1985) Fnzyme linked immuno sorbent assay (ELISA) for quality control in beer. European
Brewery Convention. Proc. 20th Congr., pp. 547-554.

Warnock, D.W. (1971). Assay in fungal mycelium in grains of barley, including the use of the fluorescent antibody technique for individual fungal species. J. Gen. Microbiol. 67, 197-205. 